\title{
Waqf as Alternative Financing Resource for Infrastructure Development in Indonesia: Analytical Hierarchy Process Approach
}

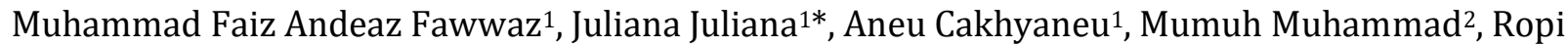 \\ Marlina $^{3}$ \\ 1 Islamic Economics and Finance, Faculty of Economics and Business Education, Universitas Pendidikan Indonesia, Indonesia \\ ${ }^{2}$ Islamic Economics and Finance, Social Science Institute, Istanbul University, Turkey \\ ${ }^{3}$ Sekolah Tinggi Ilmu Ekonomi Dr. Khez. Muttaqien, Indonesia
}

\section{ARTICLE INFO}

Keywords

Waqf Utilization Strategy,

Productive Waqf, Infrastructure

Development

\section{*Correspondence \\ julian@upi.edu}

\section{Article History}

Received 11 September 2020

Accepted 7 November 2020

Published online 8 November 2020

\section{ABSTRACT}

The productive Waqf can be utilized for developing infrastructure in Indonesia as this country has incredible waqf potential. However, the utilization of waqf assets has not been specified for infrastructure development, which has many benefits (maslahah) for Indonesia. This study aims to determine the main problem in utilizing Waqf for infrastructure development in Indonesia from regulatory dimension, management dimension, program dimension, and literacy dimension. The data analysis technique used in this study is Analytical Hierarchy Process (AHP). This study has five experts to deliver their perspective regarding problems and solutions for infrastructure development using productive Waqf in Indonesia. The study results indicate that the severe problem in utilizing productive Waqf for infrastructure in Indonesia based on experts' agreement is the Lack of professional waqf (nazhir) management in managing waqf assets. With increasing the professionalism of nazhir in the management of productive Waqf, the waqf assets are expected to grow gradually that can be used to develop and improve infrastructure in Indonesia. Lastly, the excellent management of Waqf will be able to attract the Muslim community's intention to donate.

\section{INTRODUCTION}

Indonesia is the country with the largest Muslim population globally, with $87 \%$ or 202.2 million people. It is excellent potential to develop Islamic economics, finance, and philanthropy in the country. However, in terms of Waqf, Indonesia can still not manage potential awqaf that exist, such as cash waqf and land waqf (Wicaksono, 2019). Based on Table 1, the data retrieved from the Indonesian Waqf Agency (BWI), the potential of waqf assets per year reaches up to IDR 2,000 trillion, including waqf land reaching 420,000 hectares. Meanwhile, the potential of Waqf realized is only IDR 400 billion. On the other hand, 337 land waqf are still not certified, and only 168 of waqf lands are already certified. Again, the Ministry of Religious Affairs shows that the amount of waqf land reaches 161,579 hectares with waqf assets spread across 366,595 locations (Setiawan, 2019).

Based on the data shown above, many of waqf assets are utilized for consumptive purposes rather than productive needs. This condition needs to be changed where Waqf can be one source for developing essential and productive sectors. If Waqf is managed productively and correctly, the Waqf can yield profit or income that can be used for many purposes such as infrastructure development. In another case, Waqf has a function for community development and empowerment at large, not only a small part of society and factions such as zakat, infaq, and shodaqoh, but also all aspects of life and class. The basic principle of Waqf is to create and maximize benefits for all. Waqf emphasizes the importance of strength and social welfare by maintaining high public confidence because public welfare can be achieved by maintaining it (International Working Group Waqf Principles, 2018)

The successful history of Waqf in community development can be seen from the rapidly growing development of the Islamic sultanate, from the education, health, and other public sectors where the evidence of this history can still be seen this time (Shulthoni \& Saad, 2018). The functions and benefits of Waqf are still not able to be adequately utilized by the managers of Waqf (nazhir); based on data available concerning waqf management, the waqf utilization has not been addressed to productive purposes in the main agenda, one of the factors is the Lack of competency nazhir in managing waqf assets (Widiastuti \& Wahyuningsih, 2018). Figure 1 shows the budget for developing infrastructure in Indonesia starting from 2015 to 2019. 
Table 1. Waqf utilization in Indonesia

\begin{tabular}{ll}
\hline The forms of Waqf & Percentage \\
\hline Mosque (Jami') & $44.88 \%$ \\
Small Mosque (Mushola) & $28.11 \%$ \\
School & $10.62 \%$ \\
Islamic Boarding School (Pesantren) & $3.32 \%$ \\
Funeral & $4.56 \%$ \\
Others & $8.51 \%$ \\
\hline Total & $\mathbf{1 0 0 \%}$ \\
\hline \multicolumn{2}{c}{ Source: (Ministry of Religion Affair, 2016) }
\end{tabular}

These days, infrastructure is on the government's main agenda, leading to an increase in the country's budget for infrastructure each year. Based on the data shown above, every year, the budget for infrastructure is going up. The highest growth is in 2017, reaching up to $44.3 \%$, and in the last year, the total budget for infrastructure is IDR 415 trillion. The infrastructure sector has quite a big impact on the community in terms of socio-economic activities. As known, building infrastructure requires a large amount of money, and the Waqf can be one of the alternative financings in supporting infrastructure development in Indonesia (Lubis \& Latifah, 2019). When a nation or country's infrastructure lacks quality or quantity, it will be a barrier to developing a nation in general, such as in some countries with low state incomes (Agenor, 2010). Moreover, infrastructure has many benefits for the community. The goal of infrastructure development is to create the Indonesian nation prosperous and liberate Indonesia from the lower-middle-income trap (Sugiarto, 2019).

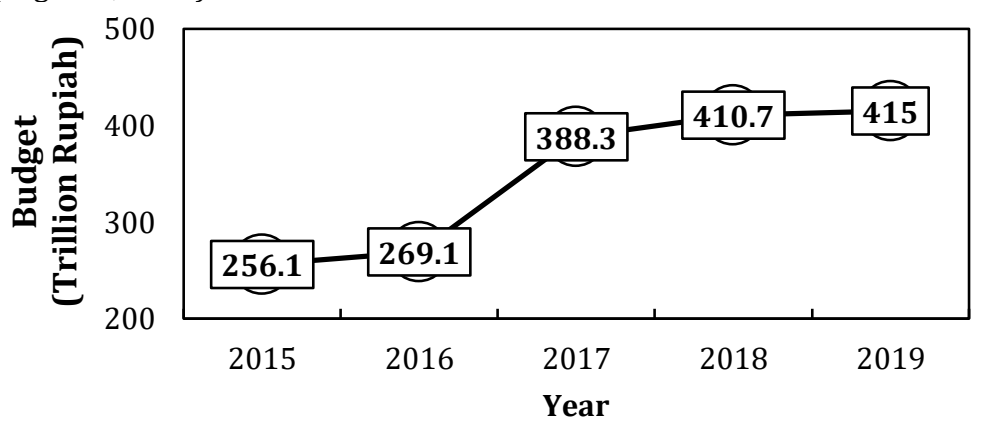

Figure 1. Infrastructure budget (trillion rupiahs) Source: (Ministry of Finance, 2019)

The Indonesian government has recently issued an innovative instrument using the waqf fund, which is Cash Waqf-Linked Sukuk (CWLS). Briefly, the profit generated from this program will be distributed and utilized for socio-economic development activities. If the Indonesian Muslims are interested in this program, then there will be a large amount of waqf fund that can be used for many purposes, including infrastructure financing. Indonesia's government is trying to find an additional fund to finance infrastructure development, and the government put great expectations to optimize waqf funds not using external debt (Hastuti, 2020).

Furthermore, productive Waqf with various schemes is also practiced in various countries. According to Abdel Mohsin (in (Pitchay, Thaker, Mydin, Azhar, \& Latiff, 2018) waqf schemes in many countries have been developed for productive purposes both dimensionally religious and socio-economic through a various program such as deposit waqf scheme (Singapore), compulsory waqf scheme (Singapore), corporate waqf scheme (India, Malaysia, Turkey, India, Pakistan, Bangladesh), and deposit waqf product (Bangladesh). Waqf schemes in many countries around the world have resulted in many benefits such as developing existing waqf land, building mosques and madrasah, financing health facilities, developing health facilities for the Muslim community, maintaining religious facilities, purchasing vehicles for preaching and Islamic teaching interests, building religious centers, depositing money to banks then invested in profitable sectors and so on (Pitchay, Thaker, Mydin, Azhar, \& Latiff, 2018). More importantly, Islamic Development Bank has initiated a great program to optimize waqf instruments for supporting economic development in the OIC member countries called Islamic Solidarity Fund for Development (ISFD). Up to the present, ISFD has conducted productive waqf development and collected millions of dollars; ISFD has three primary programs, which are poverty alleviation program, microfinance development program, and village development program (Saad, Kassim, \& Hamid, 2016). Based on the potential of Waqf and the needed budget for infrastructure development in Indonesia explained. This study would discuss and address the productive Waqf as alternative financing and support for infrastructure development.

\section{RESEARCH METHOD}

Research design is a process required in the planning and implementation of research in the community. In another way, the research design contains only a collection of analysis and data (Nazir, 2011). There are six research designs in the mixed method: equal explanatory, sequel exploratory, sequel transformative, concurrent triangulation, concurrent nested, concurrent transformative (Creswell, 2014). In this study, the research design used is sequel exploratory, a design that focuses on qualitative data collection followed by quantitative data collection measures accompanied by analysis using counting tools.

Meanwhile, the data analysis method used in this study is Analytic Hierarchy Process (AHP). AHP is a flexible model that provides opportunities for individuals or groups to create various ideas and strategies and describe problems by creating hypotheses and obtaining the desired solution (Nugeraha, 2017). There are three basic principles of AHP, namely:

a. Describing hierarchically or break down the problem into separate elements

b. Distinguishing priority and synthetic or ranking elements according to their relative importance

c. Assuring that logically classified elements are warned stably according to acceptable criteria. 
According to Saaty (in (Sasongko, Astuti, \& Maharani, 2017) there are four axioms (something that cannot be denied) that must be considered when using the AHP model:

a. Reciprocal comparison, meaning that decision-makers must be able to make comparisons and state their preferences. The preference must meet the reciprocal requirements, namely, if A is preferred over B with a scale of $x$, then B is preferable to A with a scale of $1 / x$.

b. Homogenety, meaning that one's preferences must be expressed on a limited scale or interpreted that the elements can be compared with one another.

c. Independence, meaning that preferences are stated by assuming that the criteria are not influenced by alternatives but by the overall objective. This shows that the pattern of influence in AHP is unidirectional or the elements in one level depending on the elements in the above level.

d. Expectations, meaning that for decision making purposes, the hierarchical structure is assumed to be complete.

According to Ascarya (2005) AHP has three main functions, namely:

a. Structuring complexity hierarchically into homogeneous clusters of factors.

b. Measurement into the ratio scale, the ratio scale is believed to be the most accurate in measuring the factors that make up the hierarchy.

c. Synthesis, which is uniting all the parts into one unit.

d. One of the main assumptions of the AHP model is that there is no absolute consistency. This is because the AHP model uses human perception as its input. Human decisions are partly based on logic and partly based on elements other than logic such as feelings, experience, intuition, and other elements, so this decision-making model should not require $100 \%$ absolute consistency.

The stages of study using the AHP method are as follows (Tanjung \& Abrista, 2013):

a. Model Construction

Model construction is Compiled based on theoretical and empirical literature studies and provides several questions to experts related to the field under study, and is also accompanied by in-depth interviews to explore the real problem.

b. Model Quantification

The quantification stage of the model uses questions in the questionnaire in the form of pairwise comparisons between elements in the cluster to determine which of the two is of greater importance and how big the difference is through a numerical scale of 1-9.

c. Results Analysis

\section{1) Geometric Mean}

The geometric mean is used to determine the respondents' assessment results and determine the results of the opinion in one group. The question is in the form of a comparison (pairwise comparison), which will then be compared and combined to create an agreement between these opinions.

2) Rater Agreement

Rater agreement is a measure that indicates the level of suitability (agreement) of the respondents (R1-Rn) to a problem in one cluster. The tool used to measure rater agreement is Kendall's Coefficient of Concordance (W; $0<\mathrm{W} \leq 1)$. $\mathrm{W}=1$ indicates a perfect fit. To calculate Kendall's $(W)$, the first thing to calculate is to rank each answer then add it up.

$$
\mathrm{R}_{\mathrm{i}}=\Sigma_{\mathrm{j}}^{\mathrm{m}}=1 \mathrm{r}_{\mathrm{i}, \mathrm{j}}
$$

The value of the average of the total ranking is:

$$
\mathrm{R}=\frac{1}{2} \mathrm{~m}=(\mathrm{n}+1)
$$

The sum of the squares of deviation (S), calculated by the formula:

$$
\mathrm{S}=\Sigma_{\mathrm{l}}^{\mathrm{n}}=1\left(\mathrm{R}_{\mathrm{i}}-\overline{\mathrm{R}}\right)^{2}
$$

So that we get Kendall's (W), namely:

$$
\mathrm{xW}=\frac{12 \mathrm{~S}}{\mathrm{~m}^{2}\left(\mathrm{n}^{3}-\mathrm{n}\right)}
$$

If the value of $\mathrm{W}=1$, it can be concluded that the expert's judgment or opinion has a perfect fit. Meanwhile, when the value of $\mathrm{W}=0$ or close to 0 , it shows a mismatch between answers or varied answers. Table 2 is an assessment for Kendall's Coefficient of Concordance:

Table 2. Kendall's Coefficient of Concordance Assessment

\begin{tabular}{cl}
\hline $\mathbf{W}$ & Interpretation \\
\hline 0 & No Agreement \\
0,10 & Weak Agreement \\
0,30 & Fair Agreement \\
0,60 & Strong Agreement \\
1,00 & Perfect Agreement \\
\hline \multicolumn{2}{l}{ Sums up from Various Sources (2019) }
\end{tabular}

Table 3 lists the experts who are involved in this study. 
Table 3. Respondent List

\begin{tabular}{llll}
\hline No & Respondent Name & Institution & Role \\
\hline 1 & Redha Sudatama & Wakavia & Practitioner \\
2 & Raditya Sukmana & Airlangga University & Academician \\
3 & Imam Teguh Saptono & Indonesia Waqf Board (BWI) & Regulator \\
4 & Andriyansyah & Dompet Dhuafa Jawa Barat & Practitioner \\
5 & Khalifah M Ali & IPB University & Academician \\
\hline
\end{tabular}

\section{RESULTS AND DISCUSSION}

\subsection{Problem Aspect}

\section{Regulatory Problem Dimension}

a. $\quad$ The Lack of socialization regarding productive Waqf for infrastructure (R1)

The critical and incredible benefits of Waqf must be delivered and informed to the Muslim community as the primary target. With the increase of Muslim's understanding as to Waqf, it is expected that they will be willing to donate and spend some of their wealth for the sake of Allah, and at the same time, they will participate in various programs conducted by waqf institutions owned by the government or private to create human well-being. The socialization or advertisement must be supported by all platforms available, both electronic and non-electronic, and the government is the main party to do this. The massive socialization can attract a lot of Muslims in participating waqf programs (Said \& Amiruddin, 2019)

b. The Lack of government participation in utilizing Waqf for infrastructure (R2)

The participation of government in waqf development is necessary because of the authority and power owned. For example, the obligation of paying taxes is always socialized and reminded by the government to its citizens, and almost all countries around the globe have a large amount of income generated from taxes. This kind of government support can be implemented in Waqf and supported by the most prominent Muslim population globally; Indonesia can acquire a large amount of waqf funds that can be used to resolve socio-economic problems in the country (Siswantoro \& Haula, 2016).

c. The government imposes infrastructure costs on national budgets (R3)

To finance infrastructure development, Indonesia often uses funds from external debt with high-interest agreement either from foreign countries or the international financial institution (Laucereno, 2019). If the country's needs are always financed by the national budget, mainly coming from external debt, then Indonesia's total external debt will increase and make Indonesia have heavy financial burdens in the future (Hanoum, 2019). So, it is necessary to find alternative resources to finance infrastructure, such as utilizing waqf funds from the Muslim community.

The authors' three regulatory issues are formulated based on the geometric mean (GmK), values obtained from 5 experts interviewed, show that the highest indicator is the Lack of socialization from the government $(0.367045)$. The government participation and infrastructure costs imposed on national budgets have an indicator score (0.308647) and (0.312325), respectively. A quick overview is described in Figure 2.

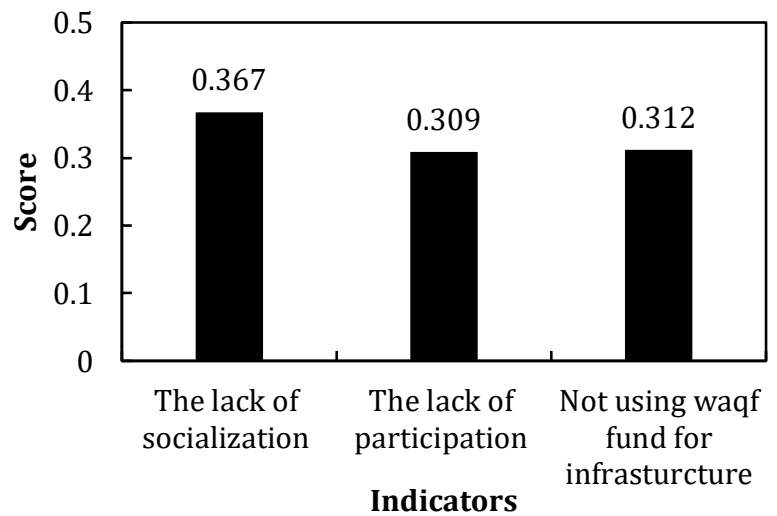

Figure 2. Indicator scores for regulatory problem dimension

\section{Program Problem Dimension}

a. The Lack of innovative programs (P1)

The waqf program for productive purposes has not been developed well by the waqf (nazhir) manager both institutionally and individually. The programs proposed are still for consumptive purposes and less innovative. Therefore, some Muslim communities have less intention to participate in the programs (Widiastuti \& Wahyuningsih, 2018).

b. The Lack of synergy between waqf institutions or stakeholders (P2)

The synergy between waqf institutions is also considered as a problem needed to be solved. Waqf institutions in Indonesia need to cooperate to create innovative programs using waqf funds; each institution needs to support each other and keep good relationships and communication. Ts is not about the competition but about developing Indonesia through the spirit of togetherness using the waqf fund (Hidayat, 2020). This result can also have an impact on strengthening the entity of waqf institutions in order to achieve the goals.

Based on the interview results from 5 experts, as seen in Figure 3, the highest indicator is the Lack of synergy between waqf stakeholders (0.489574). While the Lack of innovative programs has a score at (0.45144.) 


\section{Management Problem Dimension}

a. $\quad$ The Lack of transparency in waqf management (M1)

In general, waqf management consists of 3 main aspects: funding, investing, managing assets, and distributing or creating benefits. In practice, nazhir, as manager of the waqf institution, sometimes has a problem in transparency primarily related to the financial report. Besides that, nazhir also sometimes retards in reporting waqf management (Khamis \& Salleh, 2018).

b. Incompetent and unprofessional nazhir (M2)

Waqf in practice will have a significant impact on society and will have a very significant impact, both in improving living standards and fulfilling humanitarian, social goals, and one of the crucial factors is how to manage the Waqf either in the form of goods or money. If the management is not professional, then the impact of Waqf will be less (Shah, 2018). Therefore, it is necessary to have a competent and professional nazhir.

After analyzing the geometric mean ( $\mathrm{GmK}$ ), the indicator score for the Lack of transparency in waqf management is 0.346572 , and another indicator has an indicator score of 0.603418.

\section{Literacy Problem Dimension}

a. The Low public understanding concerning productive Waqf for infrastructure (L1)

The low understanding of society about Waqf also becomes one of the main problems in waqf management. Without participation from the Muslim community, creating productive Waqf will have less impact (Mahdiah, Hasanah, \& Nursyamsiah, 2019).

b. The Lack of building branding about productive waqf program for infrastructure (L2)

The development of creative campaign models by utilizing various media is also considered necessary because sometimes campaigns for waqf programs are still traditional and less attractive to young people (Azis, 2020). Public understanding that impacts the Lack of waqf participation needs to be addressed with a proactive campaign targeting the Muslim community to be interested in Waqf and channels Waqf for the great benefit (septiyani, 2016).

c. The difficult access to get any information concerning stakeholders using Waqf for infrastructure (L3)

Easy access to any programs using waqf funds is quite essential; the easy access and openness can attract the Muslim community to donate for productive waqf programs (Lubis \& Latifah, 2019).

Based on geometric mean ( $\mathrm{GmK}$ ) calculation as seen in Figure 3, the Lack of public understanding has the highest indicator in this dimension at 0.500403 . Meanwhile, the Lack of building branding and the problematic access have scored at 0.262946 and 0.214419 .

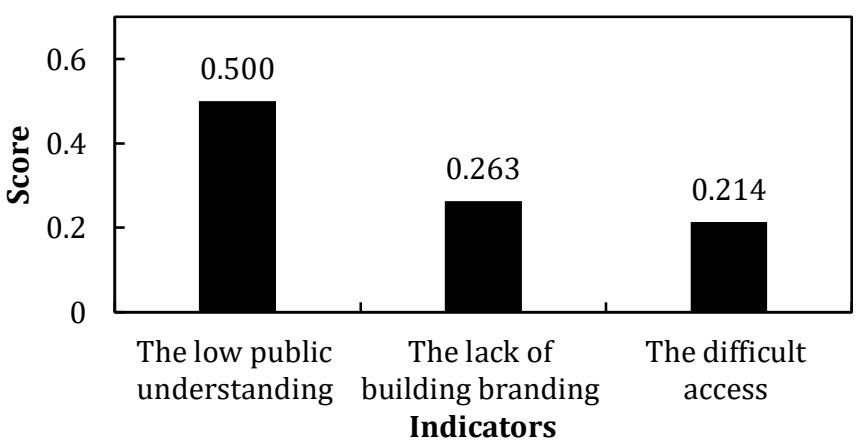

Figure 3. Indicator scores for literacy problem dimension

The geometric mean ( $\mathrm{GmK}$ ) should be calculated for all indicators. Finally, from all indicators, the indicator of incompetent and unprofessional nazhir (M2) is considered a significant problem was respecting waqf management in Indonesia with an indicator score of 0.154002 . If Waqf (nazhir) managers have good competency and professionalism in managing Waqf through various unique and innovative programs, then the waqf assets will grow and accumulate powerful resources that can be used for infrastructure development in Indonesia. The scores for all problem indicators are summarized in Figure 4.

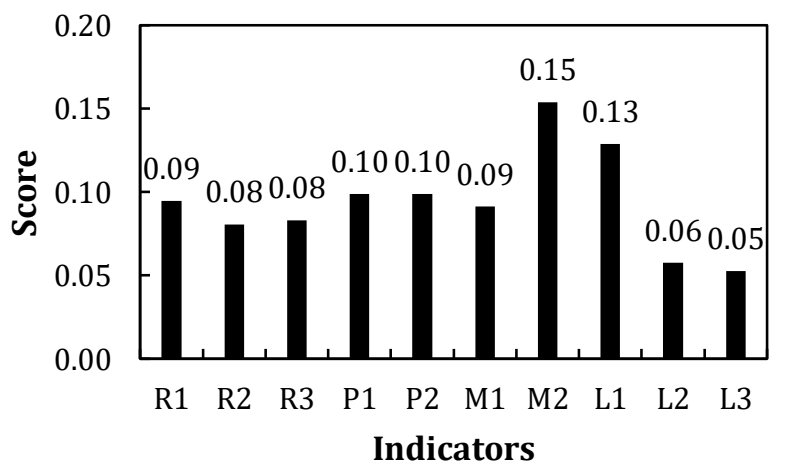

Figure 4. The scores for all problem indicators

The next step is calculating the geometric mean ( $G m K$ ) for four dimensions: regulatory dimension, program dimension, management dimension, and literacy dimension. Based on calculation results, the management dimension becomes the dimension with the highest score, which means that the management dimension is the main problem related to managing and organizing Waqf in Indonesia. After the management dimension, the literacy dimension appears as the second problematic dimension. Indonesia has the largest Muslim population, but unfortunately, the Muslim understanding regarding Waqf has not shown good condition. Therefore, Indonesia has great potential to create good achievement in Waqf. The next problematic dimension is the 
program dimension, where the waqf programs are still destined for consumptive purposes. The last problematic dimension is the regulatory dimension. Figure 4 shows the score for each dimension.

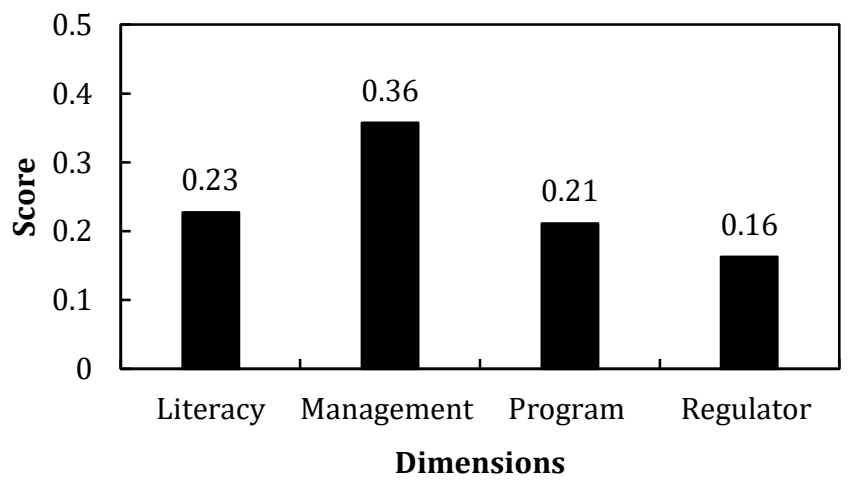

Figure 5. The scores for all problem dimensions

\subsection{Solution Aspect}

\section{Regulatory Solution Dimension}

a. Improving socialization of waqf program for infrastructure (RS1)

The waqf program for infrastructure must be socialized massively by the government to Muslim society. Socialization can be done through innovative ways and platforms, either electronic or non-electronic. The better socialization is, the better Muslim participation will be in terms of waqf program development.

b. Increasing government participation in productive waqf programs (RS2)

The government involvement in any productive waqf programs is quite essential. The government can utilize waqf funds as an alternative resource for infrastructure development. Government has the power to encourage and regulate waqf management in Indonesia.

c. Optimizing waqf fund for infrastructure (RS3)

Newly, Indonesia's government has issued a program using a waqf instrument, namely cash waqf-linked sukuk (CWLS). This program is addressed to finance government expenditure such as building infrastructure. However, the government needs to issue and create another program to gain more waqf funds. Eventually, the infrastructure development will grow faster.

Of the three solutions shown above, the experts prioritized the solution to increasing the waqf program's socialization for infrastructure to the community, which has an indicator score of 0.374180472 . The next priority is increasing government participation in productive waqf programs, and the last is optimizing waqf funds for infrastructure. A complete overview of the rating on regulatory dimension solutions can be seen in Figure 6

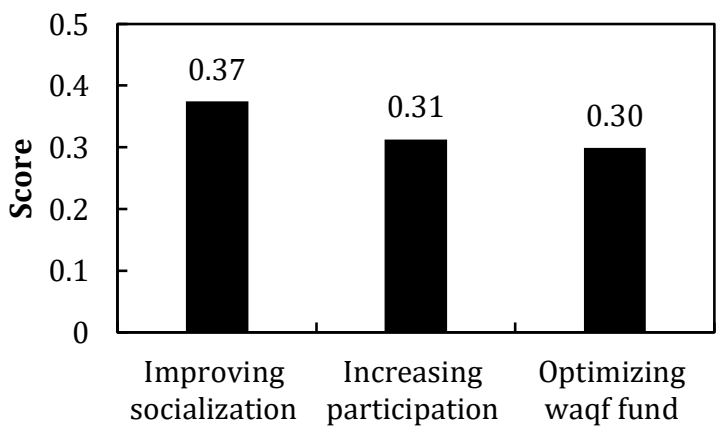

Regulatory Solution Dimension

Figure 6. Indicator scores for regulatory solution dimension

\section{Program Solution Dimension}

a. Creating an innovative waqf program for infrastructure (PS1)

The purpose of creating an innovative waqf program for infrastructure is to attract the Muslim community to be interested in the waqf program for infrastructure. On the other hand, by creating innovative programs, it is expected to benefit society through infrastructure development.

b. Strengthening synergy among waqf institutions (PS2)

To provide many benefits for society and waqf institutions' existence becomes institution boosting infrastructure development, it is necessary to have good partnership among waqf institutions. In other words, it is not about the competition because this kind of institution is not for commercial purposes but is part of Islamic philanthropy in Islam that has a function for promoting socio-economic welfare.

After interviewing five experts, between to solutions proposed, the first solution, which is creating an innovative waqf program for infrastructure, is the first preference where it has an indicator score of 0.517282 . After creating an innovative waqf program, it is essential to have good synergy among waqf institutions at 0.45032 . 
a. Increasing accountability and transparency (MS1)

Transparency is something that has to be carried out by the waqf manager (nazhir). This aspect is a must because transparency will create a good impact on waqf institutions; for example, the Muslims will trust to put their Waqf in the institutions and finally collect many waqf funds.

b. Improving nazhir competency and professionalism (MS2)

With improving professionalism, the nazhir will be able to lead waqf organizations to create many benefits. The competent and professional nazhir can manage and organize waqf funds properly and optimize Waqf for consumptive and productive purposes. The capable nazhir is the key to developing Waqf.

Between the two solutions in the management dimension above, improving nazhir professionalism (score 0.581811) is the first preference to solve the management dimension problem. After that, accountability and transparency (score 0.383852) become the next solution for solving the waqf problem in terms of the management aspect.

\section{Literacy Solution Dimension}

a. Increasing public understanding about productive Waqf for infrastructure (LS1)

The promotion and campaign about the benefit of Waqf to the Muslim community are significant. The campaign can be implemented in public places such as schools, mosques, universities, offices. On the other hand, an effective Waqf campaign can also be conducted through online platforms or social media. The more promotion, the better public understanding.

b. Building good branding of productive Waqf for infrastructure (LS2)

To build good branding, waqf institutions or other parties can use any platforms, both electronic and non-electronic. The branding can use any creative themes that persuade Muslim society to build waqf programs for infrastructure.

c. Facilitating easy access to waqf management for infrastructure (LS3)

Each waqf institution must provide access to an effective waqf program for infrastructure to society. Many people, particularly wakif (waqf payer), can easily control any programs using waqf funds.

Among the three solutions above, increasing public understanding is the leading indicator in the dimension of literacy. The next step is to build good branding about productive Waqf for infrastructure, and the last is to facilitate access to waqf organization for the public. Figure 7 depicts the indicator score for every indicator.

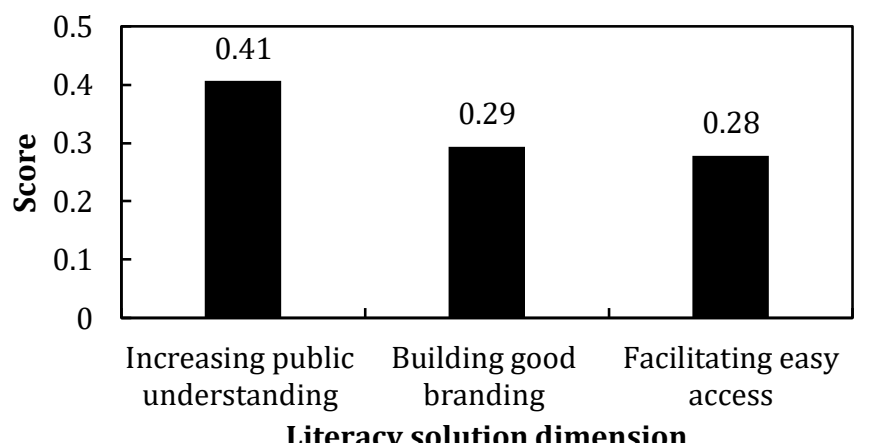

Figure 7. Indicator scores for literacy solution dimension

In total, there are ten solutions for developing productive Waqf for infrastructure. Of all the questions posed to experts, the most prioritized solution is improving nazhir competency and professionalism in managing productive Waqf to be utilized in infrastructure development. The next priority is to increase the public's understanding of the allocation of productive Waqf for infrastructure. The priority of the third solution is to increase accountability and transparency in fund management. For a complete description. Figure 8 shows the scores for each solution indicator:

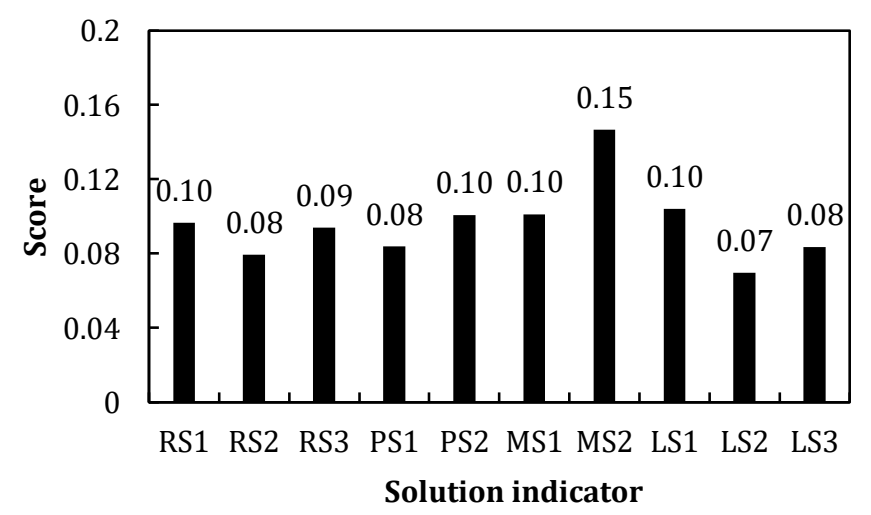

Figure 8. The scores for all solution indicators

After discussing all indicators' solution, the next step is to determine the significant solution dimension for Indonesia's waqf management. Based on interview results and processed by calculating $G m K$, the management dimension is generally prioritized in the management solution dimension. The next solution priority is the literacy dimension, and the third dimension is the program 
dimension. Meanwhile, the last dimension of the solution priority is the regulatory dimension. A clear overview of the results of the solution calculation can be seen in Figure 9.

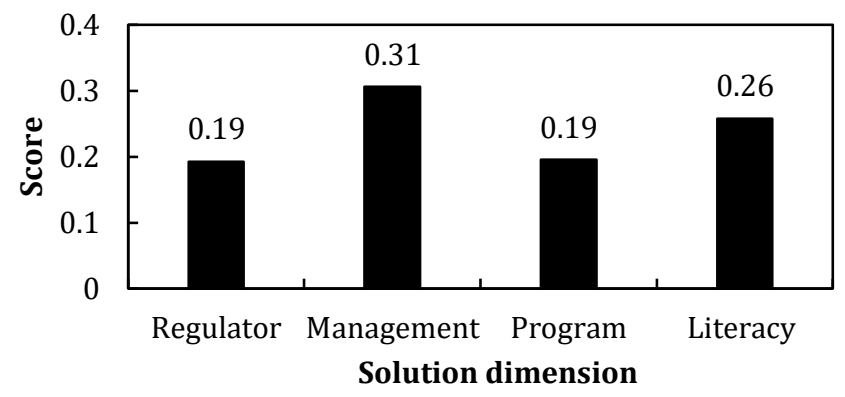

Figure 9. The Scores for All Solution Dimensions

\subsection{Experts' Agreement}

This study's experts' agreement is calculated through the Rater Agreement with Kendall's Coefficient or $W$ value as its size. The following are the experts' agreement results regarding problem and solution aspects:

\section{Problem Aspect}

From Table 4, the management dimension has a healthy level of agreement, which means that experts assess this dimension without significant differences so that perfect agreement is achieved. It also explains that the management dimension is the most problematic dimension in terms of waqf organization. Besides that, the literacy dimension also has a strong agreement, which means that this dimension is one of Indonesia's waqf organization's serious problems. The experts approve two dimensions which show serious problem concerning waqf management in Indonesia. So, all related parties should pay more attention to these dimensions and find out the appropriate solutions.

Table 4. Kendall's Coefficient for Problem Dimensions

\begin{tabular}{llll}
\hline No & Dimension & W & Description \\
\hline 1. & Regulator & 0,188089 & Weak Deal \\
2. & Program & 0,036667 & No deal \\
3. & Management & 5,28 & Strong Deal \\
4. & Literacy & 2,97 & Strong Deal \\
5. & Overall & 0,119904 & Weak Deal \\
6. & Public & 0,166833 & Weak Deal \\
\hline
\end{tabular}

\section{Solution Aspects}

Based on experts' agreement, the management and literacy aspect is the highest priority for waqf management in Indonesia, as tabulated in Table 5. There is a relationship between problem and solution aspects where both are from the management and literacy aspects. On the other hand, in the solution aspect, experts decide that the program also must be made effective as the programming aspect is one aspect that has a high deal from experts.

\begin{tabular}{|c|c|c|c|}
\hline No & Aspects & $\mathbf{W}$ & Description \\
\hline 1. & Regulator & 0,146667 & Weak Deal \\
\hline 2. & Program & 0,916667 & High Deal \\
\hline 3. & Management & 2,346667 & High Deal \\
\hline 4. & Literacy & 1,5767 & High Deal \\
\hline 5. & Overall & 0,006222 & No Deal \\
\hline 6. & Public & 0,256667 & Weak Deal \\
\hline
\end{tabular}

\section{CONCLUSION}

Among all problem indicators, the main problem regarding productive waqf utilization for infrastructure development is the Lack of competent and professional nazhir. This result is based on strong agreement among experts selected by authors. On the other hand, among all dimensions, the central problem dimension is the management aspect. Meanwhile, in terms of solution indicators, improving competent and professional nazhir is the prioritized solution that must be implemented in Indonesia. Then, the management dimension is the primary solution dimension that needs to carry out to solve the problem facing waqf organization in Indonesia. Under the Indonesia waqf board, Indonesia's government has to set some right policies regarding improving the competency, skill, and professionalism of nazhir through various programs such as training and education, seminar, workshop. The nazhir must have enough knowledge about Waqf, including fiqh, financial, management, organization, and other aspects. Furthermore, experts also believe that literacy and productive Waqf program for infrastructure must also be organized and managed appropriately. If all related parties work together to develop Waqf productive for infrastructure, it is possible to make Indonesia a top and role model country regarding productive waqf management and infrastructure development. 


\section{References}

Agenor, P. R. (2010). A Theory of Infrastructure Led-Development . Centre for Growth and Business Cycle Research, Economic Studies, 2.

Ascarya. (2005). Analytic Network Process (ANP) Pendekatan Baru Kualitatif. Jakarta.

Azis, I. N. (2020, Juli 27). Strategi Wakafpreneur. Retrieved from republika.id: https://www.republika.id/posts/6369/strategiwakafpreneur.

Creswell, J. W. (2014). Research Design: Qualitative, Quantitative, and Mixed Methods Approaches. Amerika Serikat: Sage Publications.

Hanoum, F. N. (2019). Pembiayaan Infrastruktur dan Peran Suku Bunga. Retrieved from investor.id: https://investor.id/opinion/pembiayaan-infrastruktur-dan-peran-suku-bunga

Hastuti, R. K. (2020). Mencari Format Baru Pembiayaan Infrastruktir Berbasis Syariah. Jakarta: CNBC.

Hidayat, R. (2020). MES Expert Webinar Series: Tinjauan Keuangan Publik Islam Dalam Rangka Pemulihan Ekonomi Nasional Pasca Pandemi Covid-19. (A. Talattov, Pewawancara)

International Working Group Waqf Principles. (2018). Core Principles For Effective Waqf Operation and Supervision. Jakarta: Bank Indonesia.

Laucereno, S. F. (2019). Kemenkeu: Utang untuk Pembangunan Infrastruktur. Retrieved from detik.com: https://finance.detik.com/infrastruktur/d-4370918/kemenkeu-utang-untuk-pembangunan-infrastruktur

Lubis, R. H., \& Latifah, F. N. (2019). Analisis Strategi Pengembangan Zakat, Infaq, Shodaqoh, Wakaf di Indonesia. Perisai: Islamic Banking and Finance Journal, 3(1), 45-56.

Mahdiah, N., Hasanah, N., \& Nursyamsiah, T. (2019). Factors Affecting Waqif's Decision in Selecting Productive Waqf (Case Study at Dompet Dhuafa Republika). Al-Muzara'ah, 7(2), 27-39.

Ministry of Finance. (2019). Visual Kemenkeu. Retrieved from kemenkeu.go.id: http://visual.kemenkeu.go.id/anggaraninfrastruktur-apbn-2019/

Ministry of Religion Affair. (2016). Retrieved from kemenag.go.id: http://siwak.kemenag.go.id/

Nazir, M. (2011). Metode Penelitian. Jakarta: Ghalia Indonesia.

Nugeraha, D. (2017). Sistem Penunjang Keputusan. Yogyakarta: Garudhawaca.

Pitchay, A. A., Thaker, M. A., Mydin, A. A., Azhar, Z., \& Latiff, A. R. (2018). Cooperative-waqf model: a proposal to develop idle waqf lands in Malaysia. ISRA International Journal of Islamic Finance, 230-231.

Saad, N. M., Kassim, S., \& Hamid, Z. (2016). Best practices of Waqf: Experiences of Malaysia and Saudi Arabia. Journal of Islamic Economics Lariba , 65-66.

Said, S., \& Amiruddin, A. M. A. (2019). Wakaf Tunai dan Pemberdayaan Ekonomi Masyarakat. Al-Mashrafiyah: Jurnal Ekonomi, Keuangan, dan Perbankan Syariah, 3(1), 43-55.

Sasongko, A., Astuti, I. F., \& Maharani, S. (2017). Pemilihan Karyawan Baru dengan Metode AHP. Jurnal Informatika Mulawarman, 12(2), 90.

septiyani, R. (2016). Telaah Strategi Penghimpunan Dana (Fundraising) Wakaf Tunai Untuk Mewujudkan Pemberdayaan Masyarakat (Studi Kasus di Baitul Maal Hidayatullah Perwakilan Jawa Timur). UIN Syarif Hidayatullah Jakarta, 146.

Setiawan, S. R. (2019, September 29). Potensi Besar Wakaf Belum Tersosialisasi Dengan Baik. Retrieved from Kompas: https://money.kompas.com/read/2019/09/27/201410426/potensi-besar-wakaf-produktif-belum-tersosialisasi-denganbaik

Shah, S. N. (2018, February 22). "Waqf: Gaining The Trust For Social Economic Sustainability". Kuala Lumpur, Malaysia.

Shulthoni, M., \& Saad, N. M. (2018). Waqf Fundraising Management: A Conceptual Comparison Between Traditional and Modern Waqf Institutions. Indonesian Journal of Islam and Muslim Societies, 8(1), 57-86.

Siswantoro, D., \& H. R. (2016). Sustainability of Cash Waqf Development in Indonesia: A Quintuple Helix Perspective. Humanika, 112-113.

Sugianto, D. (2019). Pemerintah Biayai 634 Proyek Pakai Utang, Ini Daftarnya. Jakarta: Detik Finance.

Sugiarto, E. C. (2019, Agustus Kamis). Melanjutkan Pembangunan Infrastruktur dan Indonesia Maju. Retrieved from setneg.go.id: https://www.setneg.go.id/baca/index/melanjutkan_pembangunan_infrastruktur_dan_indonesia_maju

Tanjung, H., \& Abrista, D. (2013). Metodologi penelitian ekonomi Islam. Jakarta: Gramata Publishing.

Wicaksono, A. (2019, November 13). BI Sebut Potensi Dana Wakaf Capai Rp3.000 Triliun. Retrieved from CNN Indonesia: https://www.cnnindonesia.com/ekonomi/20191113173328-78-448047/bi-sebut-potensi-dana-wakaf-capai-rp3000triliun

Widiastuti, T., \& Wahyuningsih. (2018). Waqf Produtictive Efficiancy: Evidence From Yayasan Bunda Wakaf Sultan Agung, Semarang. Advances in Social Science, Education and Humanities Research (ASSEHR), 98(178). 